Gynecol. obstet. Invest. 1984;18:I-VI

\title{
Contents, Vol. 18, 1984
}

\section{No. 1 Original Paper}

Immunocytochemical Localization of Keratin in Normal, Dysplastic and Neoplastic Cervi cal Epithelium

Bychkov, V.; Chejfec, G 1

Effects of 17ß-Estradiol on a Permanent Line of Rat Endometrial Cells Grown in vitro and in vivo

Hagerman, D.D.; Merrill, D.A.; Gould, S.F 6

Changes in Apolipoprotein AI after Treatment with High-Dose Medroxyprogesterone Acetate

Crona, N.; Enk, L.; Friberg, L.G.; Samsioe, G.; Silfverstolpe, G 16

Influence of Acute Estrogenic Withdrawal on Blood Calcitonin

Pansini, F.; Bettocchi, S., Jr.; Bergamini, C; Bianchi, A.; Ambrosecchia, R.; Bagni, B.;

Mollica, G 21

Changes in Soluble Proteins in Cervical Mucus during Midcycle in Normally Menstruating

Women

Fleetwood, L.; Landgren, B.-M.; Eneroth, P 27

Effects of Repeated Sampling on the Properties of the Cervical Mucus during One Day at

Midcycle

Fleetwood, L.; Landgren, B.-M

Psychological Distress and Amniocentesis

Michelacci, L.; Fava, G.A.; Trombini, G.; Zielezny, M.; Bovicelli, L.; Orlandi, C. . . 40

Trace Metals in Postdate Pregnancy

Kiilholma, P.; Erkkola, R.; Pakarinen, P.; Grönroos, M 45

Human Chorionic Gonadotrophin and Pregnancy-Specific Beta-1-Glycoprotein in Predict ing Pregnancy Outcome and in Association with Early Pregnancy Vomiting

Kauppila, A.; Heikinheimo, M.; Lohela, H.; Ylikorkala, 049

Book Reviews 54

No. 2 Original Paper

Morphologic Differentiation of Human Immature Teratoma Cell in vitro

Uehara, S.; Naganuma, T.; Hoshiai, H.; Yajima, A.; Suzuki, M 57

Degree of Female Stress Urinary Incontinence: an Objective Classification by Simultaneous Urethrocystometry

Kujansuu, E.; Heikkinen, J.; Riippa, P.; Kauppila, A 66

Chromosome Abnormalities in 118 Couples with Recurrent Spontaneous Abortions

Tóth, A.; Gaál, M.; Bösze, P.; László, J

72

Hormone Levels in Amniotic Fluid and Maternal Serum in Women Who Undergo Sponta neous Abortion after Second Trimester Amniocentesis

Bremme, K; Eneroth, P.; Nilsson, B 78

Contents

Variations in Urinary Levels of Free 6ß-Hydroxycortisol, Cortisol, and Estrogens in Late 
Pregnancy

Hunter, D.J.S.; Keane, P.; Walker, W.H.C.; YoungLai, E.V 83

Histochemical Localization of Pregnancy-Associated Plasma Protein A in Fetal, Infant, and Adult Organs and Comparison between Antisera

Schindler, A.-M.; Bischof, P 88

The Stromal Architecture of the Immature Intermediate Villus of the Human Placenta.

Functional and Clinical Implications

Castellucci, M.; Schweikhart, G.; Kaufmann, P.; Zaccheo, D 95

Critical Assessment of Antibacterial Properties of Human Amniotic Fluid

Larsen, B.; Davis, B.; Charles, D 100

Serum Levels of Ritodrine during Oral Maintenance Therapy

Smit, D.A.; Essed, G.G.M.; de Haan, J 105

Current Investigation

Effect of Administration of Progesterone on BhCG Blood Level in Early Pregnancy. Prelim inary Report

Yosef, S.M.; Nesher, R.; Navot, D.; Hadani, P.E.; Anteby, S.0

Book Review 116

Original Paper

Oncofetal Antigens in Ovarian Cyst Fluids

Kraly, D.H.; Koh, S.H.; Hay, D.L.; Cauchi, M.N

Natural Killer Cell Activity in Patients with Abnormalities of the Uterine Cervix

Neill, W.; Norval, M 122

Do Aspirin and Acetaminophen Affect Total Menstrual Loss?

Pendergrass, P.B.; Ream, L.J.; Scott, J.N.; Agna, M.A 129

Short-Term Effect of Oophorectomy on Lipoprotein Metabolism

Pansini, F.; Bergamini, C; Bettocchi, S., Jr.; Bassi, P.; Malfaccini, M.; Bagni, B.; Mollica, G. 134

Effects of an Antiestrogen on Subfractions of HDL Cholesterol during Estrogen Replacement

Therapy

Ottosson, U.B.; Carlström, K.; Johansson, B.G.; von Schoultz, B 140

Obtained Pregnancies by AID Using Frozen Semen in Relation to Specific Qualities of the

Semen

Nielsen, N.C.; Risum, J.; Brogaard Hansen, K.; Nissen, U 147

Zinc Concentration of Amniotic Fluid in the Course of Pregnancy and Its Relationship to

Fetal Weight and Length

Dura Travé, T.; da Cunha Ferreira, R.M.C.; Monreal, I.; Ezcurdia Gurpegui, M.; Villa-

Elízaga, 152

Calcium, Parathyroid Hormone and Calcitonin in Normal Pregnancy and Preeclampsia

Pedersen, E.B.; Johannesen, P.; Kristensen, S.; Rasmussen, A.B.; Emmertsen, K.; Møller, J.;

Lauritsen, J.G.; Wohlert, M 156

Puerperal Ultrasonic Hysterography

Land, J.A.; Stoot, J.E.G.M.; Evers, J.L.H 165

Announcement 151

Contents

$\mathrm{V}$

No. 4 Original Paper 
A Comparison of Plasma Cholesterol, Triglycerides and High Density Lipoprotein Choles terol Levels in Women Using Contraceptive Pills and a Control Group Yeshurun, D.; Barak, C; Blumensohn, R.; Rosenzweig, B 169

Sex Steroid Hormones Influence the cAMP Content in Human Endometrium during the Menstrual Cycle

Pansini, E; Bergamini, CM.; Bettocchi, S., Jr.; Malfaccini, M.; Santoiemma, M.; Scoppetta, V.; Bagni, B.; Mollica, G 174

Evidence of Immunosuppressor Factor in the Serum of Women Taking Oral Contraceptives Bousquet, J.; Fizet, D 178

Pubertal and Menstrual Disorders of Female Runners, Skiers and Volleyball Players

Ronkainen, H.; Pakarinen, A.; Kauppila, A 183

Increased Rate of Glucose Intolerance in Endometrial Cancer - a Community-Based

Study

Levran, D.; Modan, M.; Menczer, J.; Dulitzy, M 190

Influence of Insemination on the Implantation of Transferred Rat Blastocysts

Carp, H.J.A.; Serr, D.M.; Mashiach, S.; Nebel, L 194

Serum Levels of Unconjugated and Total Oestrogens and Dehydroepiandrosterone, Proges terone and Urinary Oestriol Excretion in Pre-Eclampsia

Rosing, U.; Carlström, K 199

Placental Alkaline Phosphatase Compared with Human Placental Lactogen and Oestriol in High-Risk Pregnancies

Ronin-Walknowska, E.; Holmgren, P.Å.; von Schoultz, B.; Stigbrand, T 206

Maternal Serum Copper and Zinc Concentrations in Normal and Small-for-Date Pregnancies

Kiilholma, P.; Grönroos, M.; Liukko, P.; Pakarinen, P.; Hyörä, H.; Erkkola, R 212

Effects of Nifedipine on Human Placental Arteries

Maigaard, S.; Forman, A.; Andersson, K.-E 217

No. 5 Original Paper

Prostaglandin and Thromboxane Production in Ovarian Cancer Tissue

Heinonen, P.K.; Metsä-Ketelä, T 225

Protease Activity in Fibromyoma and Normal Human Myometrium

Milwidsky, A.; Gal, A.; Mayer, M 230

Retroperitoneal Metastatic Spread of Malignant Brenner Tumor

Friedman, M.; Peretz, B.A.; Blumenthal, N 234

The Effect of an Hi Blocker, Chlorpheniramine Maleate, on Total Menstrual Loss

Pendergrass, P.B.; Scott, J.N.; Ream, L.J.; Agna, M.A 238

Collagen and Glycosaminoglycans in the Human Ovarian Capsule with Polycystic Ovarian

Disease

Mori, Y.; Hasumi, F.; Ito, A.; Shiina, K.; Hirakawa, S 244

Predictive Value of Uterine Contractility and the Serum Levels of Progesterone and Oestrogens with Regard to Preterm Labour

Smit, D.A.; Essed, G.G.M.; de Haan, J 252

Retrograde Time-Scale Analysis of Human Placental Lactogen, Beta Human Chorionic

Gonadotropin, and Unconjugated Estriol Levels in Human Maternal Serum from the

Onset of Spontaneous Labor

Fumhashi, N.; Tachibana, Y.; Shinkawa, O.; Takahashi, T.; Tanaka, M.; Hiruta, M.;

Suzuki, M 264 


\section{Contents}

Uteroplacental Blood Flow in Pregnancy Hypertension after the Administration of a BetaAdrenoceptor Blocker, Pindolol

Lunell, N.O.; Nylund, L.; Lewander, R.; Sarby, B.; Wager, J 269

Effect of Zinc Nutrition on Parturition and Postpartum in the Rat

Dura Travé, T.; Puig Abulí, M.; da Cunha Ferreira, R.M.C.; Villa Elízaga, 1

No. 6 Review

Immunological Aspects of Pathological Pregnancy (Infertility Immunology)

Mettler, L.; Paul, S 281

Original Paper

Computed Tomography in Staging Untreated Patients with Cervical Cancer

van Engelshoven, J.M.A.; Versteege, C.W.M.; Ruys, J.H.J.; de Haan, J.; Sanches, H. . 289

Relative Fatty Acid Composition of Lecithin during Postmenopausal Replacement Therapy -

A Comparison between Ethinyl Estradiol and Estradiol Valerate

Ottosson, U.B.; Lagrelius, A.; Rosing, U.; von Schoultz, B 296

Ultrasonic Screening in Predicting the Time of Ovulation

Jaffe, R.; Ben Aderet, N 303

Metabolism of Prostaglandin F $2 \alpha$ in the Fetal Circulation of the Human Term Placenta in vitro

Ekblad, U.; Erkkola, R.; Uotila, P 306

Ultrastructure of Human Placenta: Effects of Maternal Drinking

Amankwah, K.S.; Kaufmann, R.C 311

Gastric Aspirate L/S Ratio and Umbilical Cord Blood Total Protein as Predictors in RDS

Ekblad, H.; Kero, P.; Välimäki, 1317

Acute Effect of Prenatal Pethidine Administration on Human Fetal Brain Cyclic AMP Levels and Ornithine Decarboxylase Activity

Persitz, E.; Mor Yosef, S.; Benalal, D 322

Author Index 327

Subject Index 329 